\title{
A mixed culture performing nitrite-dependent anaerobic methane oxidation and the nitrite removal mechanism revealed by high-throughput sequencing
}

\author{
Han $\mathrm{Yan}^{1,2}$, Jianzheng $\mathrm{Li}^{1,2^{\dagger}}$, Jia Meng, ${ }^{1,2}$ Xin Wang, ${ }^{1,2}$ Lianggang Tang ${ }^{1,2}$, Avinash Kumar Jha ${ }^{1,2}$ \\ ${ }^{1}$ State Key Laboratory of Urban Water Resource and Environment, Harbin Institute of Technology, Harbin, 150090, PR China \\ ${ }^{2}$ School of Environment, Harbin Institute of Technology, Harbin, 150090, PR China
}

\begin{abstract}
Nitrite-dependent anaerobic methane oxidation (n-DAMO) has been regarded as a promising effective approach to nitrogen removal from wastewater. However, n-DAMO bacteria are very difficult to be enriched in biological wastewater treatment processes. An anaerobic sequencing batch reactor (AnSBR) was introduced in the present study for the enrichment of n-DAMO bacteria with cornfield soil as inoculum. Fed with nitrite $\left(\mathrm{NO}_{2}{ }^{-}\right)$ and methane as the specific substrates, a $\mathrm{NO}_{2}^{-}$load removal as high as $46.16 \mathrm{mg} /(\mathrm{L} \cdot \mathrm{d})$ was obtained in the AnSBR since the $232^{\text {nd }}$ day of enrichment culturing, though the relative abundance of Candidatus Methylomirabilis referring to n-DAMO bacteria was $2.37 \%$ in the acclimatized mixed culture. High-throughput sequencing of the obtained mixed culture revealed that the community structure was complex with the coexistence of n-DAMO bacteria, methanotrophs, heterotrophic denitrifying bacteria and hydrolytic fermentation bacteria. Analysis of interactions among the prevalent microbial populations suggested that Candidatus Methylomirabilis had played a key role in the metabolic network of the mixed culture. The research work presented a novel approach to the enrichment of n-DAMO bacteria from cornfield soil and was helpful in understanding the role of n-DAMO bacteria in complex matrices.
\end{abstract}

Keywords: Community structure, Methanotrophs, Mixed culture, Nitrite-dependent anaerobic methane oxidation (n-DAMO), Nitrite removal

\section{Introduction}

Methane $\left(\mathrm{CH}_{4}\right)$, which is mainly produced by methanogens in anaerobic environments, is widely distributed in nature [1,2] and accounts for almost $20 \%$ of global warming every year [3]. It has been reported that the methane produced in wetlands alone is as high as about $1.03 \times 10^{8}$ tons per year [4], but most of which are consumed before being released into atmosphere [5]. On the other hand, wastewater treatment plants (WWTPs), regarded as the emission sources of greenhouse such as carbon dioxide $\left(\mathrm{CO}_{2}\right)$ and $\mathrm{CH}_{4}$, have also attracted increasing attention [6, 7]. It was reported that about 52,600 tons of $\mathrm{CH}_{4}$ were emitted from the WWTPs of China in 2012 [8]. Meanwhile, a lot of efforts have been made to solve the shortage of organic carbon sources in biological denitrification of wastewater [9]. Recently discovered denitrifying anaerobic methane oxidation (DAMO) not only suggests a link of carbon and nitrogen cycles, but also

This is an Open Access article distributed under the terms of the Creative Commons Attribution Non-Commercial License (http://creativecommons.org/licenses/by-nc/3.0/) which permits unrestricted non-commercial use, distribution, and reproduction in any medium, provided the original work is properly cited.

Copyright (C) 2022 Korean Society of Environmental Engineers presents a potential bioprocess for the synchronous removal of nitrite and dissolved methane in anaerobic condition [10, 11]. Raghoebarsing and coworkers discovered that some bacteria could oxidize methane to carbon dioxide $\left(\mathrm{CO}_{2}\right)$ while reducing $\mathrm{NO}_{2}^{-}$to nitrogen gas $\left(\mathrm{N}_{2}\right)$ in anaerobic environment, which has been defined as nitrite-dependent anaerobic methane oxidation (n-DAMO) as Eq. (1) [10].

$$
\begin{gathered}
8 \mathrm{NO}_{2}^{-}+3 \mathrm{CH}_{4}+8 \mathrm{H}^{+} \rightarrow 4 \mathrm{~N}_{2}+3 \mathrm{CO}_{2}+10 \mathrm{H}_{2} \mathrm{O} \\
\Delta G_{0}^{\prime}=-928 \mathrm{~kJ} / \mathrm{mol}^{-1}
\end{gathered}
$$

High-throughput sequencing is widely used to analyze the microbial community and understand microbial function and diversity with high accuracy and low cost. It is carried out through sequencing by synthesis and the exclusive reversible termination of chemical reactions which could identify most kinds of microbes in the environment [12]. With the help of

Received March 15, 2021 Accepted July 08, 2021

${ }^{\dagger}$ Corresponding author

E-mail: jianzhengli@hit.edu.cn

Tel: +86-451-86283761 Fax: +86-451-86283761

ORCID: 0000-0001-7985-6378 
high-throughput sequencing, Candidatus Methylomirabilis oxyfera could be first identified from canal sediments [13, 14]. More and more n-DAMO bacteria, such as Candidatus Methylomirabilis sinica, Candidatus Methylomirabilis limnetica and Candidatus Methylomirabilis lanthanidiphila have also been found in the enrichment culture of paddy soil [15], deep stratified lake [16] and ditch sediment [17], respectively. All of the species in Candidatus Methylomirabilis have been affiliated to the phylum of NC10. Radioisotope tracer of ${ }^{14} \mathrm{C}$ revealed that anaerobic methane oxidation was coupled to denitrification by denitrifying methanotrophs as illustrated as Eq. (1) [18]. Candidatus Methylomirabilis has also been detected from various environments such as WWTPs [19], the sediment of lake and river [20], coastal sediment [21], and paddy-peatlands [22]. Obviously, n-DAMO bacteria are widely distributed in nature.

Though any pure cultures of n-DAMO bacteria have not been obtained so far, a few efforts have been contributed to enrich n-DAMO bacteria in wastewater treatment systems for denitrification [23]. With the mixture of lacustrine sediment and activated sludge as inoculum, an enrichment culture of n-DAMO bacteria had been obtained after being enriched for $260 \mathrm{~d}$ at $22^{\circ} \mathrm{C}$, in which $15 \%$ of bacteria were identified as Candidatus Methylomirabilis [24]. Another enrichment culture dominated by Candidatus Methylomirabilis oxyfera was also obtained from anaerobic sludge after acclimatization for about $300 \mathrm{~d}$, which presented a well n-DAMO phenomenon at ambient temperature $\left(20-23^{\circ} \mathrm{C}\right)[19]$. To understand the effect of reactor configuration on n-DAMO process, magnetic stirred gas lift reactor (MSGLR), sequencing batch reactor (SBR), and continuous stirred tank reactor (CSTR) had been evaluated by an enrichment culture of n-DAMO bacteria [25]. A membrane biofilm reactor (MBfR) was also performed for 24 months to demonstrate the feasibility of anammox coupled to n-DAMO for nitrogen removal from wastewater [26]. Inoculated with the sludge collected from a denitrifying bioreactor, n-DAMO activity in a membrane bioreactor could be observed after the acclimatization period as long as $388 \mathrm{~d}$ [11]. It has also been reported that via the enhancement of conductive materials, n-DAMO bacteria could produce more oxygen for methane oxidation of type I aerobic methanotrophs and form a steady and efficient microbial community to remove nitrite [27].

Beyond any doubt, enrichment cultures are not only feasible substitutes of pure cultures to perform n-DAMO in wastewater treatment processes [23], but also the alternative samples for investigating physiological ecological and biochemical characteristics of the bacteria. AnSBR is an efficient reactor to enrich anaerobic bacteria due to its simple structure and unique setting phase during the operation, which microbes were not easily washed off. Thus, cornfield soil was inoculated into an anaerobic sequencing batch reactor (AnSBR) for the enrichment of n-DAMO bacteria in the present research. And then, microbial community structure of the acclimatized mixed culture was further revealed by the high-throughput sequencing to understand the role of n-DAMO bacteria in the cycle of carbon and nitrogen in anaerobic environment, which might give guidance for the application of n-DAMO bacteria on wastewater treatment.

\section{Materials and Methods}

\subsection{Inoculum and Medium}

The inoculum for the enrichment of n-DAMO bacteria was a soil sample collected from a cornfield after harvest. Geographic location of the sampling point and the specific characters of the sample were illustrated in Table 1 . The collected sample was kept at $4^{\circ} \mathrm{C}$ for further use.

The medium according to the previous researches was used to enrich n-DAMO bacteria [13, 28]. The medium consisted of the following ingredients per liter of distilled water: $0.25 \mathrm{~g} \mathrm{KHCO}_{3}$, $0.05 \mathrm{~g} \mathrm{KH}_{2} \mathrm{PO}_{4}, 0.3 \mathrm{~g} \mathrm{CaCl}_{2} \cdot 2 \mathrm{H}_{2} \mathrm{O}, 0.2 \mathrm{~g} \mathrm{MgSO}_{4} \cdot 7 \mathrm{H}_{2} \mathrm{O}, 0.069 \mathrm{~g}$ (1 mmol) $\mathrm{NaNO}_{2}, 0.5 \mathrm{~mL}$ acidic trace element solution (100 mmol/L $\mathrm{HCl}$ ) and $0.2 \mathrm{~mL}$ alkaline trace element solution. The acidic trace element solution (100 mmol/L HCl) contained (per liter): 2.085 g $\mathrm{FeSO}_{4} \cdot 7 \mathrm{H}_{2} \mathrm{O}, 0.068 \mathrm{~g} \mathrm{ZnSO}_{4} \cdot 7 \mathrm{H}_{2} \mathrm{O}, 0.12 \mathrm{~g} \mathrm{CoCl}_{2} \cdot 6 \mathrm{H}_{2} \mathrm{O}, 0.5 \mathrm{~g}$ $\mathrm{MnCl}_{2} \cdot 4 \mathrm{H}_{2} \mathrm{O}, 0.32 \mathrm{~g} \mathrm{CuSO}_{4}, 0.095 \mathrm{~g} \mathrm{NiCl}_{2} \cdot 6 \mathrm{H}_{2} \mathrm{O}$ and $0.014 \mathrm{~g} \mathrm{H}_{3} \mathrm{BO}_{3}$. The alkaline trace element solution $(10 \mathrm{mmol} / \mathrm{L} \mathrm{NaOH})$ contained (per liter): 0.067g $\mathrm{SeO}_{2}, 0.050 \mathrm{~g} \mathrm{Na}_{2} \mathrm{WO}_{4} \cdot 2 \mathrm{H}_{2} \mathrm{O}$ and $0.242 \mathrm{~g} \mathrm{Na}_{2} \mathrm{MoO}_{4}$. The medium was flushed with nitrogen gas $\left(\mathrm{N}_{2}\right)$ for 20 min to drive out oxygen $\left(\mathrm{O}_{2}\right)$, and the $\mathrm{pH}$ adjusted to $7.0-7.5$ by $\mathrm{HCl}$ $(1 \mathrm{~mol} / \mathrm{L})$ and $\mathrm{NaOH}(1 \mathrm{~mol} / \mathrm{L})$.

Table 1. Geographic Location and Specific Characters of the Sampled Soil

\begin{tabular}{lc}
\hline Items & Values \\
\hline Coordinate & $47^{\circ} 9^{\prime} 52^{\prime \prime} \mathrm{N} 124^{\circ} 13^{\prime} 27^{\prime \prime} \mathrm{E}$ \\
Altitude & $140 \mathrm{~m}$ \\
Depth & $40-60 \mathrm{~cm}$ \\
Temperature & $7.2^{\circ} \mathrm{C}$ \\
$\mathrm{pH}$ & 7.55 \\
$\mathrm{TOC}$ & $47.16 \mathrm{~g} / \mathrm{kg}$ \\
$\mathrm{NH}_{4}^{+}$ & $121.12 \mathrm{mg} / \mathrm{kg}$ \\
$\mathrm{NO}_{2}^{-}$ & $6.06 \mathrm{mg} / \mathrm{kg}$ \\
$\mathrm{NO}_{3}^{-}$ & $38.25 \mathrm{mg} / \mathrm{kg}$ \\
\hline
\end{tabular}

\subsection{Enrichment of n-DAMO Bacteria}

The reactor for n-DAMO bacteria enrichment was a $1.2 \mathrm{~L}$ glass bottle which was operated as an anaerobic sequencing batch reactor (AnSBR) (Fig. 1). The soil sample was sifted by a $0.25 \mathrm{~mm}$ mesh sieve after grinding and then inoculated into the reactor at a mixed liquor volatile suspended solids (MLVSS) of $6.0 \mathrm{~g} / \mathrm{L}$. Sealed with a rubber stopper, the reactor was loaded with $700 \mathrm{~mL}$ of the medium and then sparged with methane (99.999\%) for 5 min acquiring about $350 \mathrm{mg} \mathrm{CH}$. The constructed reactor was put on a constant temperature magnetic stirrer (HDL apparatus, China) and incubated at $140 \mathrm{rpm}$ and $30^{\circ} \mathrm{C}$ which is favorable for the growth of n-DAMO bacteria $[14,29]$. The AnSBR was operated stage by stage with the operation cycle of 3,2 or $1 \mathrm{~d}$ which was determined by the volumetric nitrite loading rate (VLR) of around 15.3, 23.0 and 46.0 $\mathrm{mg} /(\mathrm{L} \cdot \mathrm{d})$, respectively. By the end of each operation cycle, the AnSBR was stood for $3 \mathrm{~h}$ and then $400 \mathrm{~mL}$ of the supernatant was discharged. Fed with $400 \mathrm{~mL}$ of fresh medium within 0.5 hours and sparged with methane for $5 \mathrm{~min}$, the renewed AnSBR 

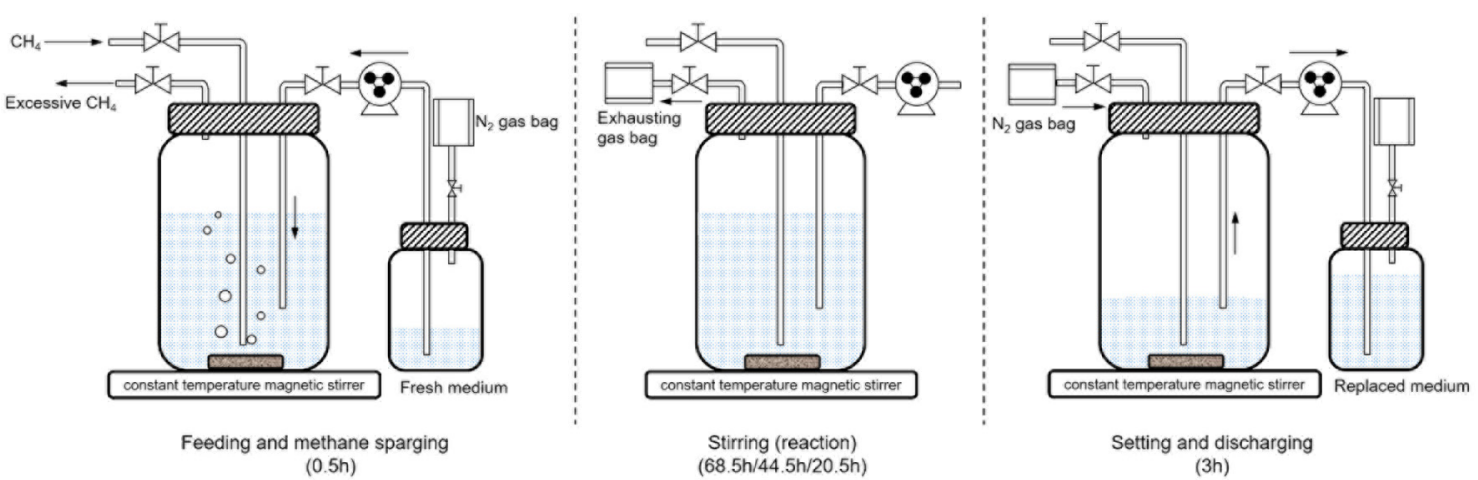

Fig. 1. Schematic diagram and operational model of the AnSBR.

was incubated again also at $30^{\circ} \mathrm{C}$ and $140 \mathrm{rpm}$. At the beginning and the end of each operation cycle, supernatant in the AnSBR was sampled for chemical analysis, respectively.

\subsection{Analytical Methods}

Nitrate $\left(\mathrm{NO}_{3}^{-}\right), \mathrm{NO}_{2}^{-}$, ammonium $\left(\mathrm{NH}_{4}^{+}\right)$, MLVSS and chemical oxygen demand (COD) were measured according to APHA standard methods [30]. Herein, $\mathrm{NO}_{3}^{-}, \mathrm{NO}_{2}^{-}$, and $\mathrm{NH}_{4}{ }^{+}$were measured using colorimetric method. MLVSS was measured through gravimetric method. COD was quantified with the method of dichromate titration. $\mathrm{NH}_{4}{ }^{+}, \mathrm{NO}_{2}^{-}$and $\mathrm{NO}_{3}^{-}$in soil were extracted using $2 \mathrm{~mol} / \mathrm{L}$ $\mathrm{KCl}$ (shaken for $1.5 \mathrm{~h}$ at $150 \mathrm{rpm}$ ) and then determined via APHA standard method. Soil temperature was measured using a temperature meter (Hach, USA). Soil $\mathrm{pH}$ was detected with a $\mathrm{pH}$ meter (Mettler Toledo, USA) after shaking soil water (1:5 w/v) suspension for $30 \mathrm{~min}$ [22]. A quantity of $200 \mathrm{mg}$ soil sample was air-dried and sieved through a $0.25 \mathrm{~mm}$ mesh for analysis of total organic carbon (TOC). The TOC was measured by an element analyzer (Vario ELcube, Elementar, Germany).

The volume fraction of $\mathrm{CH}_{4}$ and $\mathrm{CO}_{2}$ in biogas was measured on a gas chromatograph (SP-6800A, China) equipped with a 2 m stainless column (packed with Porapak Q (100 to 180 mesh)) and a thermal conductivity detector (TCD) [31]. Temperature of the oven, injection port, and detector were all set at the same $80^{\circ} \mathrm{C} . \mathrm{N}_{2}$ was used as the carrier gas at a flow rate of $40 \mathrm{~mL} / \mathrm{min}$. The injection volume was $0.5 \mathrm{~mL}$.

\subsection{High-throughput Sequencing}

To understand the microbial community structure of the mixed culture, the suspended sludge in the AnSBR was sampled by the end of the enrichment process (the $232^{\text {nd }}$ day) and then delegated to Sangon Biotech Co., Ltd (Shanghai, China) for high-throughput sequencing. DNA of the sample was isolated with E.Z.N.A Soil DNA Kit (OMEGA, USA) according to the manufacture's instruction. Bacterial 16S rDNA for the V3-V4 regions were amplified with primer pairs 341f (5'-CCTACGGGAGGCAGCAG- $\left.3^{\prime}\right)$ and $805 \mathrm{r}\left(5^{\prime}\right.$ -GACTACHVGGGTATCTAATCC-3') [32]. Composition of V3-V4 regions in the PCR products was sequenced on the Illumina Miseq sequencing platform. Raw sequences were filtered to remove low-quality reads and clustered into Operational Taxonomic Units (OTUs) at $97 \%$ of sequence similarity using QIIME v1.8.0 (USA) according to the NCBI taxonomy database. The community diversity and richness were calculated using Mothur 1.30.1. Sequence clusters were created using NCBI Blast+ 2.28 (USA). Indices of Chaos, ACE, Shannon, Simpson and Coverage were all calculated by the online website software (http://www.mothur.org/).

\section{Results and Discussion}

\subsection{Enrichment Process of n-DAMO Bacteria}

Inoculated with $6.0 \mathrm{~g}$ MLVSS/L of the cornfield soil, enrichment of n-DAMO bacteria was conducted in the AnSBR for $232 \mathrm{~d}$. All through the enrichment process, the $\mathrm{NO}_{2}^{-}$in feed was kept at about $46.0 \mathrm{mg} / \mathrm{L}$ to avoid the possible toxicity to bacteria [33]. As illustrated in Fig. 2, the enrichment process was divided into two stages, with the first $104 \mathrm{~d}$ and the last $128 \mathrm{~d}$ as Stage 1 $\left(\mathrm{S}_{1}\right)$ and Stage $2\left(\mathrm{~S}_{2}\right)$, respectively. Considering the slow growth and poor adaptability of n-DAMO bacteria to a strange environment, the AnSBR was started up at an operational cycle of $3 \mathrm{~d}$ till to the $53^{\text {rd }}$ day, which was marked as the first phase $\left(S_{1-1}\right)$ of $S_{1}$ by the VLR of $\mathrm{NO}_{2}^{-}$as low as $15.3 \mathrm{mg} /(\mathrm{L} \cdot \mathrm{d})$. As shown in Fig. 2(a), $\mathrm{NO}_{2}^{-}$removal in the reactor was rapidly increased to $95.6 \%$ within the first $17 \mathrm{~d}$, with $2.17 \mathrm{mg} / \mathrm{L}$ of $\mathrm{NO}_{2}^{-}$remaining in the effluent. However, the removal efficiency of $\mathrm{NO}_{2}^{-}$decreased gradually within the next $38 \mathrm{~d}$. By the end of $\mathrm{S}_{1-1}$ (the $55^{\text {th }}$ day), the residual $\mathrm{NO}_{2}^{-}$ in effluent averaged $13.8 \mathrm{mg} / \mathrm{L}$ with a removal rate as low as $69.3 \%$ in the reactor. To encourage the growth of n-DAMO bacteria, the VLR of $\mathrm{NO}_{2}^{-}$was increased to $23.0 \mathrm{mg} /(\mathrm{L} \cdot \mathrm{d})$ by shortening the operational cycle to $2 \mathrm{~d}$ in the second phase $\left(\mathrm{S}_{1-2}\right)$ of $\mathrm{S}_{1}$. However, $\mathrm{NO}_{2}{ }^{-}$removal in the reactor was further decreased at the $\mathrm{NO}_{2}{ }^{-}$ VLR of $23.0 \mathrm{mg} /(\mathrm{L} \cdot \mathrm{d})$. The $\mathrm{NO}_{2}^{-}$removal during the steady state ( $62^{\text {nd }}$ to $77^{\text {th }}$ days) of $\mathrm{S}_{1-2}$ averaged $43.2 \%$ (26.3 $\mathrm{mg} / \mathrm{L}$ in effluent), suggesting the metabolic activity of n-DAMO bacteria was persistently inhibited in the AnSBR.

In the present research work, the inoculum was the soil sampled from a cornfield after harvest, which was rich in biodegradable organics (Table 1). It was thought that the degradation of organic carbon sources had stimulated the growth of chemoheterotrophic microorganisms, resulting in the restriction of n-DAMO bacteria in the AnSBR [34]. It is known that hydrolysis of organics is the rate-limiting step of anaerobic digestion [35]. With few hydrolysates 

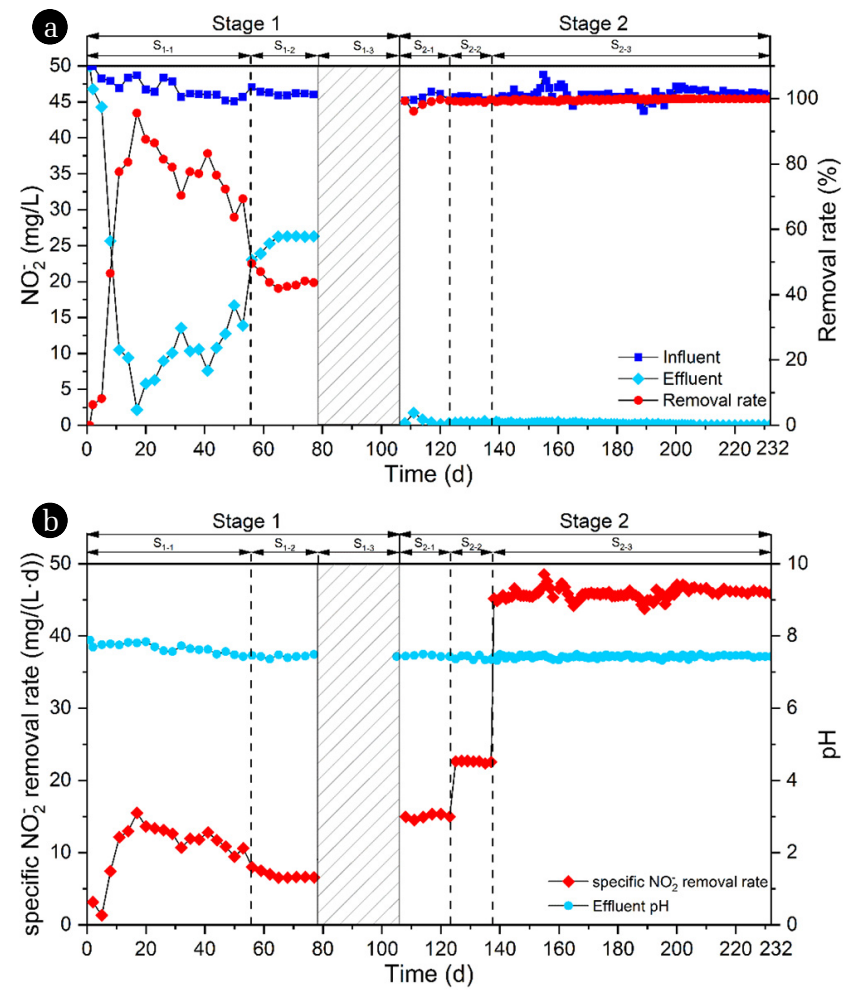

Fig. 2. $\mathrm{NO}_{2}{ }^{-}$removal (a) and specific removal rate (b) in the AnSBR during the enrichment process of n-DAMO bacteria.

of organics, the growth of chemoheterotrophic microorganisms should be badly restricted in the first $17 \mathrm{~d}$ of $\mathrm{S}_{1}$, which would provide an opportunity for the multiplication of autotrophic n-DAMO bacteria (Fig. 2(a)). Along with the extension of culturing time, more hydrolysates were released from the organics, resulting in the flourishing of chemoheterotrophic bacteria in the AnSBR. With the slow growth and metabolism, the autotrophic n-DAMO bacteria must have been obviously restricted since the $18^{\text {th }}$ day in $S_{1}$ [36]. To avoid the negative effect of chemoheterotrophic bacteria on the enrichment of n-DAMO bacteria, the AnSBR went through a 27-day idle period, the third phase $\left(S_{1-3}\right)$ of $S_{1}$, to exhaust the available organic carbon sources.

After the idle period $\left(\mathrm{S}_{1-3}\right)$, the AnSBR was restarted at the $\mathrm{NO}_{2}{ }^{-}$ VLR of $15.3 \mathrm{mg} /(\mathrm{L} \cdot \mathrm{d})$ with the operation cycle of $3 \mathrm{~d}$, which was marked as the first phase $\left(S_{2-1}\right)$ of $S_{2}$. At the beginning of $S_{2-1}$, the COD concentration in the reactor decreased under the detection limit. As expected, the bad $\mathrm{NO}_{2}^{-}$removal in $\mathrm{S}_{1}$ was restored in $\mathrm{S}_{2}$. As shown in Fig. 2(a), $\mathrm{NO}_{2}^{-}$in feed was almost exhausted all through the $128 \mathrm{~d}$ in $\mathrm{S}_{2}$, although set $\mathrm{NO}_{2}^{-}$VLR had been increased from 15.3 to 23.0 and then to $46.0 \mathrm{mg} /(\mathrm{L} \cdot \mathrm{d})$ with the operation cycle of 3,2 and $1 \mathrm{~d}$ in the $\mathrm{S}_{2-1}$, second phase $\left(\mathrm{S}_{2-2}\right)$ and third phase $\left(\mathrm{S}_{2-3}\right)$, respectively. $\mathrm{CH}_{4}$ consumption and $\mathrm{CO}_{2}$ production were found along with the excellent removal of $\mathrm{NO}_{2}^{-}$. As shown in Fig. 3, the average volume fraction of $\mathrm{CH}_{4}$ in the gaseous phase was decreased from the initial $80.6 \%$ to $73.8 \%$ by the end of the operational cycles, along with $4.1 \% \mathrm{CO}_{2}$ detected, in $\mathrm{S}_{2-3}$. The continuous $\mathrm{CH}_{4}$ consumption and $\mathrm{CO}_{2}$ production along with the excellent removal of $\mathrm{NO}_{2}^{-}$indicated that n-DAMO bacteria had been

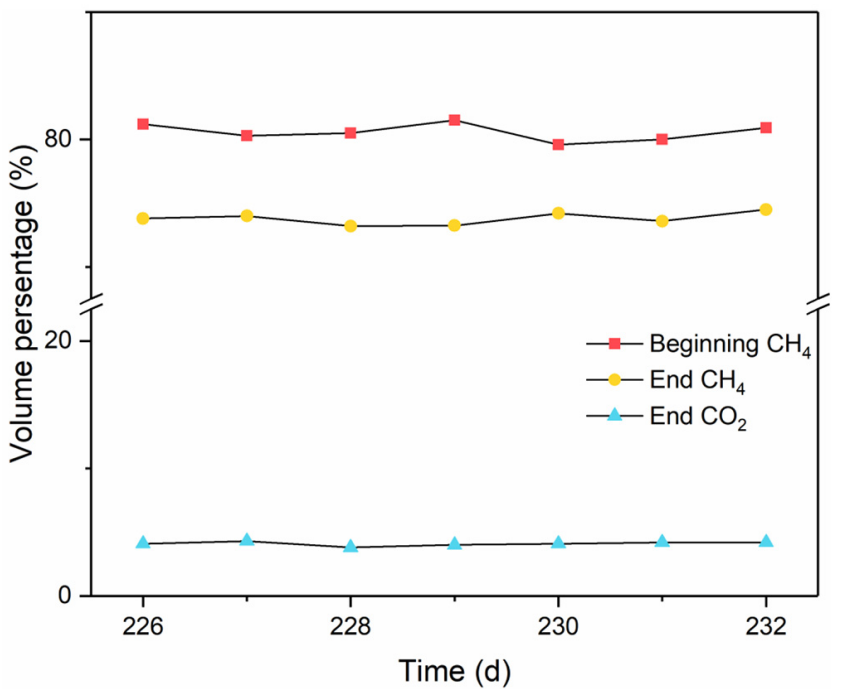

Fig. 3. The composition of gas at the beginning and end of an operational cycle in the steady phase of $S_{2-3}$ (the $226^{\text {th }}$ day - the $232^{\text {nd }}$ day).

enriched stage by stage $[11,14]$. Within the last phase $S_{2-3}$, the actual specific $\mathrm{NO}_{2}^{-}$removal rate in the AnSBR averaged 46.16 $\mathrm{mg} /(\mathrm{L} \cdot \mathrm{d}$ ) with a constant $\mathrm{pH}$ of about 7.4 (Fig. 2(b)) that was attributed to the buffers of $\mathrm{KHCO}_{3}$ and $\mathrm{KH}_{2} \mathrm{PO}_{4}$ in the medium. By the end of $\mathrm{S}_{2-3}$, MLVSS in the AnSBR was detected to be $6.87 \mathrm{~g} / \mathrm{L}$, i.e. the specific $\mathrm{NO}_{2}^{-}$removal rate of the acclimatized mixed culture was about $6.72 \mathrm{mg} /(\mathrm{g}$ MLVSS$\cdot \mathrm{d})$.

\subsection{Community Structure of the Acclimatized Mixed Culture}

On the $232^{\text {nd }}$ day, the mixed culture in the AnSBR was sampled for high-throughput sequencing to reveal the microbial community structure and functional bacterial diversity. With the good coverage of $0.97,35942$ clean reads were obtained and clustered into 1404 OTUs at $97 \%$ of sequence similarity. Indices Shannon, Simpson, Chao1 and ACE of the mixed culture were 4.24, 0.04, 4974.12 and 9259.12, respectively. The results suggested that the species of the enrichment were diverse [37].

To reveal the removal pathways of $\mathrm{NO}_{2}^{-}$in the mixed culture, microbial community structure on phylum and genus level was further analyzed. The phylum assignment (Fig. 4(a)) showed that Proteobacteria, Bacteroidetes and Chloroflexi were the most abundant three phyla in the culture, with a relative abundance as high as $46.81 \%, 17.2 \%$ and $12.03 \%$, respectively. Most denitrifying bacteria are classified into the three phyla [38]. Latescibacteria and Acidobacteria were also rich in the mixed culture with a relative abundance of $5.73 \%$ and $4.65 \%$, respectively. Bacteria affiliated to Latescibacteria mainly exist in soil and function in degrading plant polysaccharide [39]. The bacteria in Acidobacteria can adapt to a low-nutrient environment [40]. As one of the phyla in which methanotrophs were cataloged, the relative abundance of Verrucomicrobia reached $2.27 \%$. Phylum NC10 has collected all of the identified n-DAMO bacteria [17], and the relative abundance reached $2.37 \%$ in the mixed culture.

As illustrated in Fig. 4(b), the unclassified bacteria accounted 

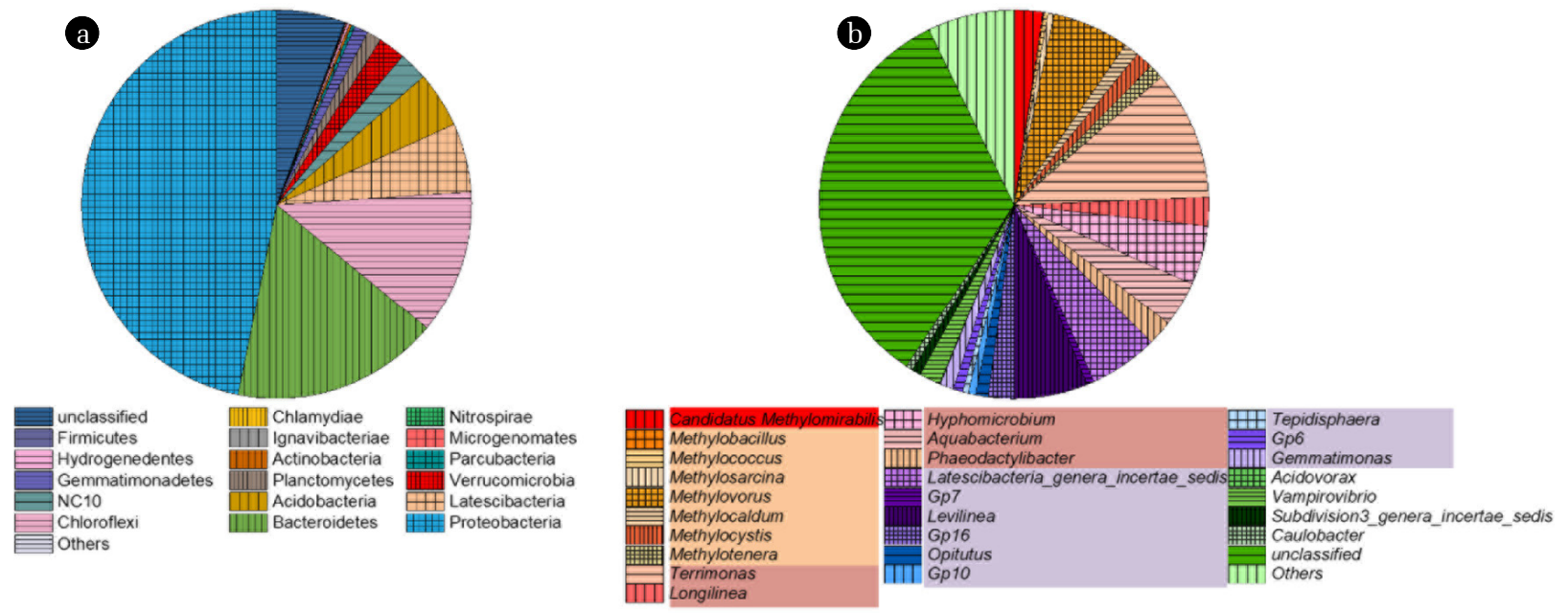

Fig. 4. Microbial community structure at (a) phylum level and (b) genus level.

for $33.48 \%$ in the mixed culture, most of which were indicated as the bacteria in phylum Proteobacteria. Besides the unclassified bacteria, Terrimonas, Methylovorus, Levilinea, Latescibacteria_genera_incertae_sedis and Hyphomicrobium were the most abundant genera, with a relative abundance of $10.75 \%, 6.36 \%, 6.12 \%, 5.73 \%$ and $4.9 \%$, respectively. Although Terrimonas is classified as an aerobic heterotrophic genus, some bacteria in the genus have been detected in anaerobic conditions [41]. Methylovorus has been described as a group of restricted facultative methylotrophic bacteria, characterized by the assimilation of methanol via ribulose monophosphate pathway and the presence of glutamate cycle enzymes for ammonia assimilation [42]. Levilinea has been indicated as acidogenic fermenters which can degrade various carbohydrates to volatile acids [43]. Chemoheterotrophic bacteria Latescibacteria_genera_incertae_sedis, mainly distributed in soil [39], was also found in the mixed culture. Hyphomicrobium has been reported as denitrifying bacteria which can convert $\mathrm{NO}_{2}{ }^{-}$ to $\mathrm{N}_{2}$ using methanol as a carbon source in anaerobic condition [44]. As the only reported genus performing n-DAMO, Candidatus Methylomirabilis accounted for $2.37 \%$ in the mixed culture. Some other methanotrophs were also found in the mixed culture, such as Methylocystis, Methylocaldum, Methylophilus, Methylosarcina and Methylococcus. All of the bacteria in the five genera have been identified as aerobic bacteria which convert methane to one-carbon substances such as methanol [45]. It was concluded that both aerobic and anaerobic methane-oxidizing bacteria coexisted in the mixed culture, which agreed with the earlier research [46]. The diversity of species and the complex microbial community suggested that a complete food web had been caused by the supplied $\mathrm{CH}_{4}$ and $\mathrm{NO}_{2}^{-}$as essential nutrients.

\subsection{Biochemical Characteristics and Nitrite Removal Approaches in the Mixed Culture}

The biodegradable organics in the soil sample (Table 1) must play a role as the electronic donors to heterotrophic denitrification of $\mathrm{NO}_{2}{ }^{-}$, which resulted in the rapid increase of $\mathrm{NO}_{2}^{-}$removal in the AnSBR within the first $17 \mathrm{~d}$. The gradually decreased $\mathrm{NO}_{2}{ }^{-}$ removal (within the days from the $18^{\text {th }}$ to $80^{\text {th }}$ day) indicated the exhaustion of biodegradable organics by the end of $\mathrm{S}_{1-2}$. Although the hydrolysates of organics in the soil could also contribute to the heterotrophic denitrification, the availability should have been severely restricted due to the refractory to biodegradation [47]. Thus, n-DAMO was identified as a dominant approach to the good $\mathrm{NO}_{2}^{-}$removal in $\mathrm{S}_{2-3}$. However, the good $\mathrm{NO}_{2}^{-}$removal should be challenged by the relative abundance of n-DAMO bacteria (Candidatus Methylomirabilis) as low as $2.37 \%$ in the mixed culture.

As shown in Fig. 4(b), the community structure of the mixed culture was complex with the coexistence of aerobic heterotrophic bacteria (Terrimonas), facultative anaerobic bacteria (Methylovorus, Aquabacterium), carbohydrate fermenting bacteria (Levilinea), chemoheterotrophic bacteria (Latescibacteria), denitrifying bacteria (Hyphomicrobium) and n-DAMO bacteria (Candidatus Methylomirabilis). The diversity of species and biochemical characteristics suggested a complex food web was established in the AnSBR. Though it was difficult to reveal the metabolic network in the mixed culture in detail, the following cooperation between the identified dominant genera could be identified as illustrated in Fig. 5: 1) the supplied $\mathrm{NO}_{2}^{-}$was reduced to $\mathrm{N}_{2}$ by Candidatus Methylomirabilis via n-DAMO with the supplied $\mathrm{CH}_{4}$ as electronic donors, during which $\mathrm{O}_{2}$ would be produced (Eq. (1), Eq. (2), and Eq. (3)) [48, 49]; 2) the produced $\mathrm{O}_{2}$ would further be absorbed and utilized by methanotrophs (Methylocystis, Methylocaldum, Methylotenera, Methylosarcina and Methylococcus) for the biosynthesis of biomass, methanol and formic acid [27, 45]; 3) the synthesized methanol and formic acid by the methanotrophs, as well as the organic acids formed by hydrolytic fermentation bacteria (Levilinea and Opitutus) [43], all served as the electronic donors for the reduction of $\mathrm{NO}_{2}^{-}$by denitrifying bacteria (Hyphomicrobium and Longilinea) with $\mathrm{CO}_{2}$ and $\mathrm{N}_{2}$ as the end products [50].

$$
\begin{gathered}
2 \mathrm{NO}_{2}^{-}+4 \mathrm{H}^{+}+2 \mathrm{e}^{-} \rightarrow 2 \mathrm{NO}+2 \mathrm{H}_{2} \mathrm{O} \\
2 \mathrm{NO} \rightarrow \mathrm{N}_{2}+\mathrm{O}_{2}
\end{gathered}
$$




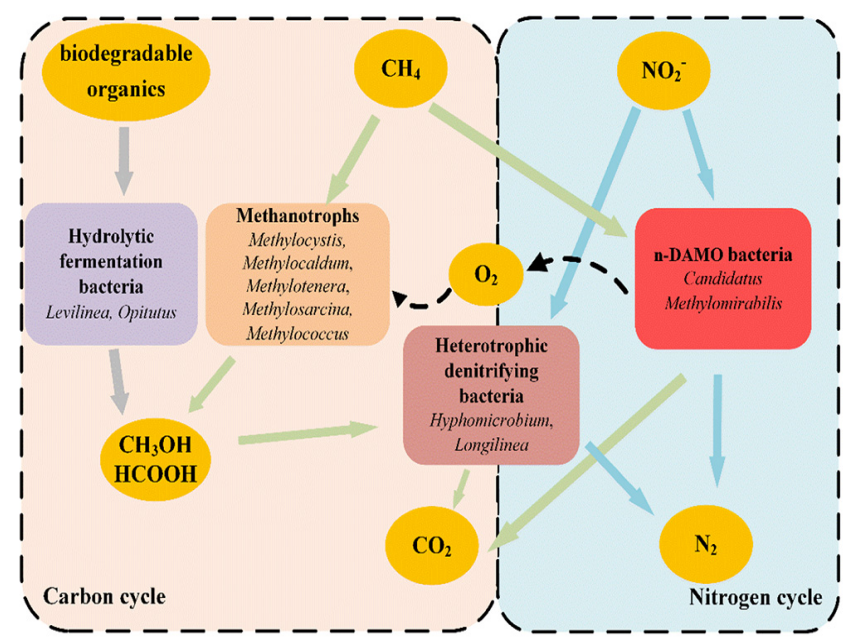

Fig. 5. Population interaction and metabolic network in the enrichment culture.

Above all, the nitrite removal approaches had been revealed in the mixed culture of n-DAMO bacteria, based on the microbial species and supplied nutrients, $\mathrm{CH}_{4}$ and $\mathrm{NO}_{2}^{-}$. Though n-DAMO had been identified as the dominant approach to $\mathrm{NO}_{2}^{-}$removal, assimilation and heterotrophic denitrification had also contributed to the $\mathrm{NO}_{2}^{-}$removal in the AnSBR. The diversity of species and biochemical characteristics suggested that the mixed culture had a high availability for nitrogen removal in wastewater treatment plants.

\section{Conclusions}

The mixed culture that contained n-DAMO bacteria was acquired in an AnSBR after 232-day cultivation inoculated from cornfield soil. The relative abundance of n-DAMO bacteria reached $2.37 \%$ in the enrichment. The specific $\mathrm{NO}_{2}^{-}$removal rate of the mixed culture was as high as $6.72 \mathrm{mg} /(\mathrm{g}$ MLVSS$\cdot \mathrm{d})$ with the $\mathrm{NO}_{2}{ }^{-}$ load removal of about $46.16 \mathrm{mg} /(\mathrm{L} \cdot \mathrm{d})$ in the AnSBR. The reactor showed a complex community structure with the coexistence of n-DAMO bacteria, methanotrophs, heterotrophic denitrifying bacteria and hydrolytic fermentation bacteria. By analyzing the biochemical characteristics and microbial community structure, we found that n-DAMO bacteria, Candidatus Methylomirabilis, played an important role in combining nitrogen cycle and carbon cycle. The present work opens a direction for the enrichment of n-DAMO bacteria and proposed the possible application of $\mathrm{n}$-DAMO bacteria in nitrite removal of the wastewater treatment plant.

\section{Acknowledgments}

This study was financially supported by the National Natural Science Foundation of China (Grant No. 51778171), the State Key Laboratory of Urban Water Resource and Environment, Harbin Institute of Technology (Grant No. 2019DX03).

\section{Author Contributions}

H.Y. (Ph.D. student) wrote the original manuscript and conducted all the experiments. J.L. (Professor) revised the manuscript and supervised the work. J.M. (Lecturer) supervised the work. X.W. (Ph.D. student) did the investigation. L.T. (Ph.D. student) did the experiments. A.K.J. (Ph.D. student) revised the manuscript.

\section{References}

1. Aiyuk S, Forrez I, Lieven DK, van Haandel A, Verstraete W. Anaerobic and complementary treatment of domestic sewage in regions with hot climates - A review. Bioresour. Technol. 2006;97:2225-2241.

2. Moujanni AE, Qarraey I, Ouatmane A. Anaerobic codigestion of urban solid waste fresh leachate and domestic wastewaters: Biogas production potential and kinetic. Environ. Eng. Res. 2019;24:38-44.

3. Knittel K, Boetius A. Anaerobic Oxidation of Methane: Progress with an Unknown Process. Annu. Rev. Microbiol. 2009;63: 311-334.

4. Bastviken DT, Tranvik LJ, Downing J, Crill P, Enrich-Prast A. Freshwater Methane Emissions Offset the Continental Carbon Sink. Science 2011;331:50-50.

5. Cicerone RJ, Oremland RS. Biogeochemical Aspects of Atmospheric Methane. Global Biogeochem. Cy. 1988;2:299-327.

6. Kojima H, Tsutsumi M, Ishikawa K, Iwata T, Mußmann M, Fukui M. Distribution of putative denitrifying methane oxidizing bacteria in sediment of a freshwater lake, Lake Biwa. Syst. Appl. Microbiol. 2012;35:233-238.

7. Brown S, Kruger C, Subler S. Greenhouse gas balance for composting operations. J. Environ. Qual. 2008;37:1396-1410.

8. Cai C, Hu S, Guo J, Shi Y, Xie GJ, Yuan Z. Nitrate reduction by denitrifying anaerobic methane oxidizing microorganisms can reach a practically useful rate. Water Res. 2015;87:211-217.

9. Kim HG, Kim JT, Ahn DH. Effects of carbon to nitrogen ratio on the performance and stability of aerobic granular sludge. Environ. Eng. Res. 2021;26(1):190284.

10. Raghoebarsing AA, Pol A, van de Pas-Schoonen KT, et al. A microbial consortium couples anaerobic methane oxidation to denitrification. Nature 2006;440:918-921.

11. Allegue T, Arias A, Fernandez-Gonzalez N, Omil F, Garrido JM. Enrichment of nitrite-dependent anaerobic methane oxidizing bacteria in a membrane bioreactor. Chem. Eng. J. 2018;347:721-730.

12. Deng ZS, Zhang B-C, Qi X-Y, et al. Root-Associated Endophytic Bacterial Community Composition of Pennisetum sinese from Four Representative Provinces in China. Microorganisms 2019;7(2):47.

13. Ettwig KF, Shima S, van de Pas-Schoonen KT, et al. Denitrifying bacteria anaerobically oxidize methane in the absence of Archaea. Environ. Microbiol. 2008;10:3164-3173.

14. Ettwig K, van Alen T, van de Pas-Schoonen KT, Jetten MSM, Strous M. Enrichment and molecular detection of denitrifying methanotrophic bacteria of the NC10 phylum. Appl. Environ. Microbiol. 2009;75:3656-3662. 
15. He Z, Cai C, Wang J, et al. A novel denitrifying methanotroph of the NC10 phylum and its microcolony. Scientific Reports 2016;6:32241.

16. Graf JS, Mayr MJ, Marchant HK, et al. Bloom of a denitrifying methanotroph, 'Candidatus Methylomirabilis limnetica', in a deep stratified lake. Environ. Microbiol. 2018;20:2598-2614.

17. Versantvoort W, Guerrero-Cruz S, Speth DR, et al. Comparative Genomics of Candidatus Methylomirabilis Species and Description of Ca. Methylomirabilis Lanthanidiphila. Frontiers in Microbiology 2018;9:1672.

18. Deutzmann JS, Schink B. Anaerobic Oxidation of Methane in Sediments of Lake Constance, an Oligotrophic Freshwater Lake. Appl. Environ. Microb. 2011;77:4429-4436.

19. Luesken FA, van Alen TA, van der Biezen E, et al. Diversity and enrichment of nitrite-dependent anaerobic methane oxidizing bacteria from wastewater sludge. Appl. Microbiol. Biotechnol. 2011;92:845-854.

20. Shen LD, Liu S, Zhu Q, et al. Distribution and diversity of nitrite-dependent anaerobic methane-oxidising bacteria in the sediments of the Qiantang River. Microb. Ecol. 2014;67:341-349.

21. Chen J, Dick R, Lin J-G, Gu J-D. Current advances in molecular methods for detection of nitrite-dependent anaerobic methane oxidizing bacteria in natural environments. Appl. Microbiol. Biotechnol. 2016;100:9845-9860.

22. Shi Y, Wang Z, He C, Zhang X, Sheng L, Ren X. Using (13)C isotopes to explore denitrification-dependent anaerobic methane oxidation in a paddy-peatland. Sci. Rep. 2017;7:40848.

23. Liu T, Hu S, Guo J. Enhancing mainstream nitrogen removal by employing nitrate/nitrite-dependent anaerobic methane oxidation processes. Crit. Rev. Biotechnol. 2019;39:732-745.

24. Hu S, Zeng RJ, Burow LC, Lant P, Keller J, Yuan Z. Enrichment of denitrifying anaerobic methane oxidizing microorganisms. Environ. Microbiol. Rep. 2009;1:377-384.

25. Hu B-1, Shen L-d, Lian X, et al. Evidence for nitrite-dependent anaerobic methane oxidation as a previously overlooked microbial methane sink in wetlands. Proc. Natl. Acad. Sci. USA. 2014;111:4495-4500.

26. Shi Y, Hu S, Lou J, Keller J, Yuan Z. Nitrogen removal from wastewater by coupling anammox and methane-dependent denitrification in a membrane biofilm reactor. Environ. Sci. Technol. 2013;47:11577-11583.

27. Chang J. Wu Q, Yan X, et al. Enhancement of nitrite reduction and enrichment of Methylomonas via conductive materials in a nitrite-dependent anaerobic methane oxidation system. Environ. Res. 2021;193:110565.

28. He Z, Geng S, Pan Y, et al. Improvement of the trace metal composition of medium for nitrite-dependent anaerobic methane oxidation bacteria: Iron (II) and copper (II) make a difference. Water Res. 2015;85:235-243.

29. Hatamoto M, Sato T, Nemoto S, Yamaguchi T. Cultivation of denitrifying anaerobic methane-oxidizing microorganisms in a continuous-flow sponge bioreactor. Appl. Microbiol. Biotechnol. 2017;101:5881-5888.

30. APHA. Standard Methods for the Examination of Water and WasteWater. 21st ed. Washington DC: American Public Health Association; 2005.

31. Zhang Y, Li J, Liu F, et al. Specific quorum sensing signal molecules inducing the social behaviors of microbial populations in anaerobic digestion. Bioresour. Technol. 2019;273 185-195.

32. Hugerth LW, Wefer HA, Lundin S, et al. DegePrime, a Program for Degenerate Primer Design for Broad-Taxonomic-Range PCR in Microbial Ecology Studies. Appl. Environ. Microbiol. 2014;80:5116-5123

33. He Z, Cai C, Geng S, et al. Mdodeling a nitrite-dependent anaerobic methane oxidation process: Parameters identification and model evaluation. Bioresour. Technol. 2013;147:315-320.

34. Kootstra AMJ, Mosier NS, Scott E, Beeftink HH, Sanders J. Differential effects of mineral and organic acids on the kinetics of arabinose degradation under lignocellulose pretreatment conditions. Biochem. Eng. J. 2009;43:92-97.

35. Li J. Chi X, Zhang Y, Wang X. Enhanced coproduction of hydrogen and butanol from rice straw by a novel two-stage fermentation process. Int. Biodeter. Biodegr. 2018;127:62-68.

36. Aiyuk S, Forrez I, Lieven DK, van Haandel A, Verstraete W. Anaerobic and complementary treatment of domestic sewage in regions with hot climates--a review. Bioresour. Technol. 2006;97:2225-2241

37. Chernov TI, Tkhakakhova AK, Kutovaya OV. Assessment of diversity indices for the characterization of the soil prokaryotic community by metagenomic analysis. Eurasian. Soil Sci. 2015;48:410-415.

38. Gonzalez-Martinez A, Osorio F, Morillo JA, et al. Comparison of Bacterial Diversity in Full Scale Anammox Bioreactors Operated Under Different Conditions. Biotechnol. Progr. 2015;31:1464-1472.

39. Youssef NH, Farag IF, Rinke C, et al. In Silico Analysis of the Metabolic Potential and Niche Specialization of Candidate Phylum "Latescibacteria" (WS3). Plos One 2015;10:0127499.

40. Ward NL, Challacombe JF, Janssen PH, et al. Three Genomes from the Phylum Acidobacteria Provide Insight into the Lifestyles of These Microorganisms in Soils. Appl. Environ. Microb. 2009;75:2046-2056.

41. Liu HZ, Yan JP, Wang Q, et al. Biodegradation of Methyl tert-Butyl Ether by Enriched Bacterial Culture. Curr. Microbiol. 2009;59:30-34.

42. Govorukhina NI, Trotsenko YA. Methylovorus, a New Genus of Restricted Facultatively Methylotrophic Bacteria. Int. J. Syst. Bacteriol. 1991;41:158-162.

43. Yamada T, Sekiguchi Y, Hanada S, et al. Anaerolinea thermolimosa sp nov., Levilinea saccharolytica gen. nov., sp nov and Leptolinea tardivitalis gen. nov., so. nov., novel filamentous anaerobes, and description of the new classes anaerolineae classis nov and Caldilineae classis nov in the bacterial phylum Chloroflexi. Int. J. Syst. Evol. Micr. 2006;56:1331-1340.

44. Timmermans P, Van Haute A. Denitrification with methanol: Fundamental study of the growth and denitrification capacity of Hyphomicrobium sp. Water Res. 1983;17:1249-1255.

45. Wei M, Qiu Q, Qian Y, Cheng L, Guo A. Methane oxidation and response of Methylobacter/Methylosarcina methanotrophs in flooded rice soil amended with urea. Appl. Soil Ecol. 2016;101:174-184.

46. Siniscalchi LAB, Leite LR, Oliveira G, Chernicharo CAL, de Araujo JC. Illumina sequencing-based analysis of a microbial 
community enriched under anaerobic methane oxidation condition coupled to denitrification revealed coexistence of aerobic and anaerobic methanotrophs. Environ. Sci. Pollut. $R$. 2017;24:16751-16764.

47. Taherzadeh MJ, Karimi K. Acid-Based Hydrolysis Processes for Ethanol from Lignocellulosic Materials: A Review. Bioresources 2007;2:472-499.

48. Ettwig KF, Butler MK, Le Paslier D, et al. Nitrite-driven anaerobic methane oxidation by oxygenic bacteria. Nature 2010;464:
543-548.

49. Ettwig KF, Speth DR, Reimann J, Wu ML, Jetten MSM, Keltjens JT. Bacterial oxygen production in the dark. Front Microbiol. 2012;3:273.

50. Zhai S, Min J, Pavlostathis SG, Zhao Y. Impact of hydraulic retention time and current on the microbial community and denitrification genes in a continuous-flow biofilm electrode reactor. J. Chem. Technol. Biotechnol. 2019;94:933-941. 